\title{
Study on Optimization and Orientation of Leisure Sports Professionals Training Program in China Based on "Teaching in 2030" in the United States
}

\author{
Chenting Zhu \\ Physical Culture Institute \\ Leshan Normal University \\ Leshan, China 614000
}

\author{
Jingtao $\mathrm{Wu}$ \\ Physical Culture Institute \\ Leshan Normal University \\ Leshan, China 614000
}

\author{
Beiguang Guan \\ Physical Culture Institute \\ Leshan Normal University \\ Leshan, China 614000
}

\begin{abstract}
The development plan of "Teaching in 2030" in the United States proposed that learners need to master knowledge and skills in an unprecedented way in a flattening world. Aiming at improving the reasonable layout of class hour and credit hour in the training program for leisure sports professionals, this paper uses the literature and statistical methods to meet the rapid development of modern educational technology and world education, and analyzes the current situation of college talent training programs in China. Besides, it dissects and clarifies the development trends and optimization path of leisure sports professionals training program in China to ensure that the training of leisure sports professionals in China meet the needs of developing flat information age in modern times.
\end{abstract}

Keywords-leisure sports; talent training program; orientation

\section{INTRODUCTION}

2015 is a milestone in the development of world education marching towards science and technology, informationization, and entering the "i-era", and is an important year for education reform and development [1]. In the same year, UNESCO published the "Actions Framework of Education in 2030" that Moves Towards Inclusive Education, Fair and High Quality Education, and Civil Lifelong Learning", (hereinafter referred to as the 2030 framework) [2], and the reflective report summary "Reflective Education: A Reflective Education: Changing to the Concept of "Global Common Core Interests" (hereinafter referred to as the Reflection Report) was issued by UNESCO on its 70th anniversary [3]. With the prospect of the "i-era" after education in the intelligent age of industry 4.0, and "4Cs learning skills" working as the core concept of development, flattening education in the 21 st century has entered a stage of rapid development, showing the paths and trends that focus on technology and career development [4].
With the help of the two frameworks and the summary report, the development plan of the "Teaching in 2030" in the United States proposes six policy measures for reforming teaching to promote the professional change of teaching in the 21 st century. Comparing with leisure sports personnel training program and teaching mode operating environment as well as the training path and mission of leisure sports professionals in China, and providing an outlook of the direction and objectives of leisure sports development, the development planning framework of "teaching in 2030" in the United States is more authoritative, deeper and referable. Based on the development plan of "Teaching in 2030" in the United States, the paper uses mathematical statistics and other research methods to sort out the phenomena and problems of leisure sports professionals training program in China, which meet the rapid development of technology in the era and the world education development, adapt to the development path of Chinese leisure sports industry, and clarify the direction for optimizing training program of leisure sports professionals in China to ensure that leisure sports professionals training program adapts to the development of the flattening information age.

\section{RESEARCH OBJECTS AND METHODS}

\section{A. Research Object}

The study relies on the development planning framework of the "Education in 2030" in the United States. It focuses on the status quo and path trending of the training programs on leisure sports professionals in 18 colleges and universities in China.

\section{B. Research Methods}

1) Literature review method: It provides a theoretical basis for the writing by looking up reference books such as "American Education Plan in 2030", "Reflection Report" 
related to leisure sports, "Leisure Sports", and etc., searching keywords of "Teaching in 2030" development plan and Leisure sports personnel training program on CNKI(China National Knowledge Infrastructure) and wanfang database with the help of the Internet platform, looking for relevant thesis and dissertation as well as core journal papers, finding relevant education personnel training programs from relevant official association websites, and learning about the latest development plans and orientation trends.

2) Mathematical statistics: Using spss22.0 software to carry out mathematical statistics, the paper sorts out the leisure sports professionals training program of representative 18 colleges and universities, and uses cluster analysis to analyze the status quo, closeness and concentrative degree of leisure sports training program in China.

\section{CONTRASTIVE ANALYSIS OF TRAINING PROGRAMS FOR LEISURE SPORTS TALENTS IN COLLEGES AND UNIVERSITIES IN CHINA}

Prof. Gong Shizu pointed out: "personnel training mode on narrow sense refers to the formalized and streamlined operation mode of cultivation process adopted in order to achieve training objectives and training specifications under the guidance of a specific education idea and education concept. It has distinctive styles and features in the implementation process, and develops towards formalization and modeling" [5]. The study aimed at the patronization of training programs for college leisure sports professionals in China and the standardization of curriculum settings. It used cluster analysis methods in statistics to analyze and compare mean values on credit hours, class hours and credits as well as the size of the colleges fit index (F) and significance (sig) in the 18 institutions within and between groups (public compulsory courses, professional basic courses, professional courses, professional elective courses). Based on the results above, issues such as the weight of curriculum provision and the closeness with relevant courses of the personnel training program in 18 institutions of higher learning in China were analyzed. It also drew lessons from the reform evaluation and accountability system in development planning of "Teaching in 2030" in the United States, and further explored and dissected the imagination of "Teaching in 2030" development planning in the United States on professional construction and curriculum planning. Based on this, it studied three dimensions of credit hours, class hours and credits to find out the similarities and differences between the development plan of "Teaching in 2030" in the United States and the current teaching development in China and lay the foundation for the optimization and orientation of training programs for college leisure sports professionals in China.

\section{A. Comparative Analysis on the Number of Class Hour for Leisure Sports Professionals Training}

TABLE I. K-MEANS CluSter ANALySIS ON THE NUMBER OF Class Hour

\begin{tabular}{|c|c|c|c|c|}
\hline Institutions & Mean square among the cluster groups & Mean square within the error groups & $\mathbf{F}$ & Sig. \\
\hline Beijing Sport University & 96.000 & .000 & . & . \\
\hline Beijing Normal University, Zhuhai & 170.667 & 50.000 & 3.413 & .316 \\
\hline Chizhou University & 112.667 & .000 & . & . \\
\hline Huainan Normal University & 37.500 & .500 & 75.000 & .073 \\
\hline Chengdu Sport University & 150.000 & 722.000 & .208 & .728 \\
\hline Jinlin Sport University & 2.667 & 2.000 & 1.333 & .454 \\
\hline Nanjing Sport Institute & 42.667 & 2.000 & 21.333 & .136 \\
\hline Putian University & 1148.167 & 12.500 & 91.853 & .066 \\
\hline Xi'an Physical Education University & 32.667 & 8.000 & 4.083 & .293 \\
\hline West Anhui University & 66.667 & 2.000 & 33.333 & .109 \\
\hline Zhengzhou Normal University & .000 & 8.000 & .000 & 1.000 \\
\hline Wuhan Sports University & 1768.167 & .500 & 3536.333 & .011 \\
\hline Shandong Sport University & 48.167 & 4.500 & 10.704 & .189 \\
\hline Sichuan Tourism College & 54.000 & 18.000 & 3.000 & .333 \\
\hline Lingnan Normal University & 37.500 & .500 & 75.000 & .073 \\
\hline Harbin Sport University & 150.000 & 50.000 & 3.000 & .333 \\
\hline Guangdong Vocational Institute of Sports & 37.500 & 40.500 & .926 & .512 \\
\hline Guangzhou Sport University & 80.667 & 72.000 & 1.120 & .482 \\
\hline
\end{tabular}

By horizontal comparing the proportion of class number and the overall weight of class hours in the course setting module for the four categories (public compulsory courses, professional basic courses, professional compulsory courses, and professional elective courses) in leisure sports specialty of 18 universities of leisure and sports in China, and analyzing the relatively larger indexes of the three colleges and universities: Huainan Normal University, Putian University and Wuhan Institute of Physical Education among F-value in "Table I", it indicates that the matching degree of the four types of courses in the three institutions is relatively high, showing that course number of the four category is balanced in the three institutions and the difference is small. On the contrary, numerical value of the four institutions including Beijing Sport University, Chizhou University, Zhengzhou Normal University and Guangdong Vocational Institute of Sports are smaller in value and less consistent, indicating that there are significant differences in the four categories of courses in the institutions. According to the sig index of "Table I", the data of Beijing Sport University, 
Chizhou University, and Wuhan Institute of Sports are all less than 0.01, indicating that there are significant differences in the class number in the four categories and the number of curriculum settings is quite different.

The development planning document of "Teaching in 2030 " in the United States points out that the future teaching orientation is the talent input path in the 21 st century based on the core skills of conceptualization, specific scenes, creativity, and the skills reserves of 4Cs. Looking at the setting of classes and class hour in the 18 leisure and sports

\section{B. Comparative Analysis on the Number of Classes Hour for Leisure Sports Professionals Training}

professional colleges mentioned above, we can find that about class hour, there are imbalance and great difference in the distribution in regional colleges and universities of leisure sports professionals training program. It shows that there is a big difference between the lesson planning and construction of current leisure sports professional courses in China with the development plan of "Teaching in 2030". It shows difference between standardization and unification of professional constructing core skills training, and the level of professional construction fails to better meet the needs of the times, which is urgent to be optimized and improved.

TABLE II. K-MEANS CluSter ANALYSIS OF CLASS Hours

\begin{tabular}{|l|l|l|l|c|}
\hline \multicolumn{1}{|c|}{ Institutions } & $\begin{array}{c}\text { Mean square among } \\
\text { the cluster groups }\end{array}$ & $\begin{array}{c}\text { Mean square within } \\
\text { the error groups }\end{array}$ & F & Sig. \\
\hline Beijing Sport University & 9408.000 & 6912.000 & 1.361 & .364 \\
\hline Beijing Normal University, Zhuhai & 352261.333 & 196997.333 & 1.788 & .313 \\
\hline Chizhou University & 67500.000 & 63075.000 & 1.070 & .410 \\
\hline Huainan Normal University & 130208.333 & 3049.333 & 42.701 & .023 \\
\hline Chengdu Sport University & 907500.000 & 1279408.000 & .709 & .488 \\
\hline Jinlin Sport University & 105281.333 & 1.300 & .372 \\
\hline Nanjing Sport Institute & 21.333 & .001 & .982 \\
\hline Putian University & 2818821.333 & 31317.333 & 165.995 & .006 \\
\hline Xi'an Physical Education University & 341.333 & 16981.333 & .947 \\
\hline West Anhui University & 44165.333 & 59733.333 & .431 & .579 \\
\hline Zhengzhou Normal University & 6348.000 & 102565.333 & .091 & .791 \\
\hline Wuhan Sports University & 7087107.000 & 69456.000 & 5733.905 & .000 \\
\hline Shandong Sport University & 147852.000 & 1236.000 & 10.474 & .084 \\
\hline Sichuan Tourism College & 3605.333 & 14116.000 & .055 & .836 \\
\hline Lingnan Normal University & 48006.750 & 65109.333 & 5.993 & .134 \\
\hline $\begin{array}{l}\text { Harbin Sport University } \\
\text { Guangdong Vocational Institute of } \\
\text { Sports }\end{array}$ & 340033.333 & 8747.000 & 94.582 & .199 \\
\hline Guangzhou Sport University & 196608.000 & 132012.0000 & .074 & .811 \\
\hline
\end{tabular}

By comparing the statistics on the number of class hour in the four categories in 18 institutions in "Table II", it can be seen from the mean square among the cluster groups of the nine institutions including Beijing Normal University, Zhuhai, Huainan Normal University, Chengdu Sport University, Jilin Sport University, Putian University, Wuhan Sports University, Shandong Sport University, Harbin Sport University and Guangzhou Sport University are relatively large, indicating that the number of class hours in these 9 institutions is relatively large in the vertical comparison among 18 institutions. It also can be seen from the mean square values in the group that Beijing Normal University, Zhuhai, Chengdu Sport University, and West Anhui University have relatively large values, indicating that the class arrangement in the four categories in the three institutions varies. From the index of F-dimension above, it can be seen that the indexes of institutions such as Huainan Normal University, Putian University, Wuhan Sports university are relatively larger, indicating that the three universities have a higher degree of integration in the number of class hours, and there is little difference in the number of class hours in the four internal categories. From the sig index dimension, we can see that indexes of Putian
University and Wuhan Sports university are both less than 0.01 , indicating that there is a significant difference in the number of class hours in the four categories.

Based on the above data list, it can be concluded that there are significant differences in the class hour arrangement of leisure sports professionals training program in China among individual institutions, and it also indicates that the colleges and universities do not have the same opinion on class hour. Seeing from the development plan of "Teaching in 2030" in the United States, it can be seen that the imagined teachers of the United States in 2030 have the ability of helping students participate in open and cooperative inquiry by using the Internet platform and evaluate student's studies by using virtualization products. It states that the United States will build virtual classroom environment and space by using the Internet platform in 2030 , which is completely superior to the current operation mode of the requisite amount and the standard amount of class hour in China. Besides, it verifies value guidance including forward-looking, contemporary and functional natures of the "Teaching in 2030" development plan once again, and also reveals the lag in the arrangement of leisure 
and sports courses in China. It is urgent to optimize the path with reference to the development plan of "Teaching in 2030".
C. Comparative Analysis on the Credits Number of Leisure Sports Professionals Training

TABLE III. K-MEANS Cluster ANALYSIS OF CREDIT NUMBER

\begin{tabular}{|l|l|l|l|l|}
\hline \multicolumn{1}{|c|}{ institutions } & $\begin{array}{l}\text { Mean square among } \\
\text { the cluster groups }\end{array}$ & $\begin{array}{c}\text { Mean square within } \\
\text { the error groups }\end{array}$ & F & Sig. \\
\hline Beijing Sport University & 24.083 & 8.333 & 2.890 & .231 \\
\hline Beijing Normal University, Zhuhai & 1180.083 & 702.333 & 1.680 & .324 \\
\hline Chizhou University & 212.521 & 120.333 & 1.766 & .315 \\
\hline Huainan Normal University & 1610.083 & 1217.583 & 1.322 & .369 \\
\hline Chengdu Sport University & 3996.750 & 5461.000 & .732 & .482 \\
\hline Jinlin Sport University & 363.000 & 306.750 & 1.183 & .390 \\
\hline Nanjing Sport Institute & 4.083 & 50.333 & .081 & .803 \\
\hline Putian University & 11071.688 & 63.000 & .006 \\
\hline Xi'an Physical Education University & 1.333 & 233.333 & 175.741 & .947 \\
\hline West Anhui University & 675.000 & 4.000 & .006 & .006 \\
\hline Zhengzhou Normal University & 1.021 & 156.083 & 168.750 & .943 \\
\hline Wuhan Sports University & 21845.333 & 4.333 & .007 & .000 \\
\hline Shandong Sport University & 432.000 & 19.000 & 5041.231 & .041 \\
\hline Sichuan Tourism College & 8.333 & 204.333 & 22.737 & .859 \\
\hline Lingnan Normal University & 27.000 & 73.000 & .041 & .605 \\
\hline Harbin Sport University & 1260.750 & 397.000 & .370 & .217 \\
\hline $\begin{array}{l}\text { Guangdong Vocational Institute } \\
\text { Sports }\end{array}$ & 27.000 & 400.000 & 3.176 & .819 \\
\hline Guangzhou Sport University & 616.333 & .068 & .459 \\
\hline
\end{tabular}

Comparing the cluster analysis of the credit number in the leisure sports professionals training model in18 colleges and universities in "Table III", it can be seen from the mean square dimension between the groups that the indexes of Putian University and Wuhan Institute of Physical Education are larger (compared to other colleges and universities), indicating that there are significant differences in the credit number of leisure sports professionals training model. The indexes of mean square in the group of Huainan Normal University and Chengdu Sport University are larger in four categories (public compulsory courses, professional basic courses, professional elective courses, and professional compulsory courses), indicating that the credits of the two institutions are relatively different. The index of Putian University and Wuhan Institute of Physical Education, which are viewed from the $\mathrm{F}$ Index, is larger, indicating that integrating degree of the credit number in the two institutions is higher. To further dig the intrinsic significance of the credits number, we can find that the indexes of Putian University, Wuhan Institute of Physical Education, and West Anhui University in the list of sig dimensions was less than 0.01 , indicating that the credit number in the three universities has significant differences.

In terms of credit recognition and evaluation, the development plan of "Teaching in 2030" in the United States proposes that there should be less connection between the nature of learning and the specific content, and students' understanding of the knowledge system should be enhanced, manifested as learning the ability to access, explore, evaluate knowledge and think deeply. It should mainly reflect students' commitment to problem solving and creativity improvement. Seeing that credit recognition of leisure sports specialty in China pays more attention to the credits for core courses, skills courses, and professional courses, we can find that we have deviated from the development plan of "Teaching in 2030" in the US at the level of values and development.

Methodology points out that phenomena and essence are both opposite and unified, and the two depend on each other [6]. The scale orientation and development trend of the total class hours, credit hours, and credits in the leisure sports professionals training program in the above-mentioned 18 institutions of higher learning is a microcosm and a true reflection of the leisure sports professionals training in China's universities. Listing the horizontal and vertical comparison among the three parts of the talent training program, it can be seen, in general, that there is a trend of balanced development of class hour, and a few (Beijing sports University, chizhou University) present the diversity development in colleges and universities in China; there is an uniform development of class hour in colleges and universities in China, showing an equalized trend in the number of class hours, and a few (Putian University, Wuhan Institute of Physical Education) show characteristic development; there is a big difference in the number of credits between horizontal and vertical comparison, and large differences in vertical comparison between a few institutions (Wuhan Institute of Physical Education, Putian University). Through the comparison and analysis of the internal phenomena of the above mentioned things, it can reflect the positioning objectives, values and development orientation of talents training in 18 colleges and universities.

Comparing with the requirements proposed by the development plan of "Teaching 2030" in the US, when developing talent training programs, leisure sports specialty construction in China has not comprehensively analyzed the current scientific and technological upgrading and the future 
development trend of education level in 2030 . It is specific in the distinction of class hours, credit hours, and credits, and reflected in the similarities and differences of values, view of quality, and development view. More specifically, the arrangement of class hour has not been conceptualized, specific, scenarized and creative any more, and the 4Cs core skills derived from the frontier of science and technology have not been shown. There are different opinions on the arrangement of credit hours in China, different from the ways that the development plan of "teaching in 2030" in the United States helps students participate in open and collaborative inquiry, and evaluate their academic orientation by means of virtualized products and works through the Internet platforms. In the arrangement of credits, there are some deviation from the development plan of "teaching in 2030" in the United States, which advocated that connection between the nature of learning and the specific content should be reduced, and students' understanding of the knowledge system should be enhanced, so dedicated efforts can be made to problem solving and creativity enhancement. In general, the three orientations of class hours, credit hours and credit are different from the development plan of "Teaching in 2030" in the United States, reflected in the lack of values, quality, and development concepts. It is urgent to optimize and orient according to the development plan of "teaching in 2030" in the United States and the local development.

\section{THE OPTIMIZATION AND ORIENTATION OF COLLEGE \\ LEISURE SPORTS PROFESSIONALS TRAINING PROGRAM}

The formulation of college leisure sports professionals training plan keeps pace with the development of the Times, conforms to the development of the times, and seeks for reform paths and development directions from the perspective of macro policies and the era development [7]. In addition, local colleges and general colleges should accord with the elements such as economic level, political atmosphere, cultural effect and regional characteristics, and find a personnel training program that matches with the characteristic running path and development of school [8].

\section{A. Optimization and Orientation of Value}

The dimensions of values are discussed and explored in depth from both human values and social values. On the one hand, social values are discussed in terms of economic functions, political functions, and cultural functions. On the other hand, human values are interpreted from the aspects such as individual functions, career selection, and growth function. As a society-based person, he should be consistent with the development of social-based values, focusing on the combination of progressive social function and the expression of humanistic values [9].

The development plan of "Teaching in 2030" in the United States pointed out that in the talent training path, it is necessary to further bridge the academic gaps, and the "No Child Left Behind Act" that focuses on student learning achievements is a failure, and its evaluation methods and values guides deviate from the values of talent cultivation [10]. At present, universities in China mainly advocate the educational idea of "people-oriented", and advocate that schools and parents pay attention to students' independent study, self-discussing and individualized balanced development, and focus on cultivating students' ability to construct and implement innovative thinking. However, they are struggling to seek out the path of practice as well as environment and atmosphere matching with reform and development, and the "people-oriented" education development concept in China has little effect. In contrast, the development plan of the "Teaching in 2030" in the United States proposes to build schools around the community and popularize subject knowledge, so as to actively promote the trend of school education in the value dimension of talent cultivation and make up for the learning and promotion of the social utility value system. It has obtained significant results [11]. The education level and concept in China differ greatly from the development plan of "Teaching in 2030" in the United States. In particular, there are serious problems in the path construction of leisure sports professionals training in the general, regional and private universities in China. There is a big gap between them and the individualized and humanist ideas of western countries. From the perspective of the long-term development of the state and the education system improvement, the construction of school knowledge system based on the community and deep excavation of education concept of "human-oriented" according to the development plan of "Teaching in 2030" in the United States is the only route as well as the victory road to the optimization and orientation of value in the process of China's current leisure sports professionals training.

\section{B. Optimization and Orientation of Quality Outlook}

Quality is an edge tool in the reform and development, and it is also an important factor that must be carefully considered in the reform and development [12]. In today's booming market economy and explosion of knowledge in colleges and universities, what kind of training quality should college development have? Whether to continue to use the traditional education talent training quality to discriminate between good and bad? These are all problems that we must face and overcome in the development of education. It is also a path development problem that must be optimized and found in college leisure sports professionals training.

There are different qualities of talent training in different periods. Under the current environment of education development, the quality of talent training cannot be measured by pure elite education [13]. Compared with the development plan of "Teaching in 2030" in the United States proposed that accountability system for teachers should not be eliminated, and the accountability system cannot focus too much on the traditional standards; it should be in line with the standard of cultivating talents in the global market of the 21 st century and show the criteria for students' organization and problems solving, research framework, problems analysis and process progress assessment, so that the quality development of education is closely linked to the development needs of The Times [14]. In the process of 
formulating training programs for leisure sports professionals in colleges and universities in China in the same period, specialized construction is carried out combined with the national ministry of education and local regional characteristics, and personnel training quality level is built to meet the needs of schools, societies and states on this basis. Comparing the development plan of "Teaching in 2030" in the United States with the market-oriented talent training program in China, there are differences and similarities. The 21 st century is a new period of diversified development, with process, diversity, and structural evaluation being the trend and orientation of the present development. How to effectively evaluate the merits of student decision-making is the development orientation of the current global education quality. It is also a practical problem for education talents training in various majors in China. Taking the o general development trend of education quality in China, the current development trend and the next development point of global education quality, the quality of training leisure sports professionals in China should actively follow the development of the Times and be in line with the professional market environment and regional cultural characteristics, actively preparing for the improvement of the training quality of leisure sports professionals.

\section{Optimization and Orientation of Development View}

Coordinated and balanced development of educational development scale, structure, quality, efficiency, and values is the scientific development path for talent cultivation [15]. It is not measured by the "tangible" development of teacher and student numbers, the number of specialized courses, and the size of campuses, but evaluated by the connotation of running a school, the professional structural system, the high-level faculty system, the improvement of running characteristics, the creation of spiritual culture and system culture.

Faced with challenges such as informatization, globalization and the boomed knowledge economy in the new century, the new concept of personnel training development is a key factor of professional development and the survival and development of colleges. The development plan of "Education in 2030" in the United States proposed that teachers should educate students to allocate attention effectively with minimum time, fully mobilize students to apply theories to studies, and make learning meaningful and effective through different design frameworks to make learning meaningful and planned [16]. In terms of class hours, credit hours, credits and course objectives in leisure sports professionals training program in China, leisure sports professionals training program in China is mainly in line with the market orientation and the ministry of education policy of "tangible" development to balance the current personnel training orientation. The development plan of "Education in 2030" in the United States and education scientific personnel training path are widely different. The talent education under the guide of development plan of "Education in 2030" in the United States is inclined to carry out education evaluation reform according to the existing teaching level of science and technology for the sake of promoting and forming the teaching mode of marketization and operational development of enterprises and drive students to develop towards the balanced development path of quality, efficiency, and large-scale. The leisure sports specialties in China mainly promote the "tangible" talent training path in line with the market orientation, and what it bring about are the curriculum construction and talent transmission with the market economy working as value orientation. To sum up, seeing from the comparison and discussion between the two, the development view of leisure sports professionals training in China should establish a scientific and coordinated outlook on development to carry out deep improvement and stability by borrowing from today's high-tech educational technology and the process evaluation system of balanced and coordinated development, as well as the teaching mode of enterprise and market operation in order to lay a foundation for the optimization and output of the development view of China's leisure sports professionals.

\section{CONCLUSION}

The training program for college leisure sports professionals should look to the world and the future, focusing on the segmentation and quantification of class hours, credit hours and credits in the training program of leisure sports talents, and develop the correct establishment and reasonable optimization of values, quality view and development view in personnel training. It should borrow current education technology and balanced process evaluation system, as well as adopt the teaching model of enterprise and marketization, optimize with the regional characteristics and actual conditions of the school to form rational and scientific development path of personnel training, and state the development direction for China's leisure sports professionals training program, so as to ensure the export of leisure sports professionals in China to meet the needs of the current and future flat information era.

\section{REFERENCES}

[1] Yang Weijia. Prospects for the Global and Chinese Education Development Direction in the Era of Education 4.0: Analysis of the Latest Report of UNESCO in 2015 [J]. Review of Higher Education, 2016, (12): 42-48. 杨维嘉. 展望教育 4.0 时代全球及中国教育的 发展方向一一联合国教科文组织 2015 年最新报告的分析 [J]. 山 东高等教育, 2016, (12):42-48.

[2] UNESCO. Education 2030 Framework [EB/OL] . [2016-04-18] http://unesdoo. unesc;o. org/images/0024/002432/243278e.

[3] UNESCO. Rethinking Education-Towards a Global Common Good'? [EB/OL].[2016 - $04-18]$ http://unesdoc. unescoorg/images/0023 $/ 002325 / 232555 \mathrm{e}$.

[4] Xu Li, Wang Mo, Cheng Huandi. A new Milestone That Global Education Moves towards Lifelong Learning: the Goal Translation of the "Action Framework for Education in 2030" [J]. Open Education Research, 2015, (06): 16-25. 徐莉, 王默, 程换弟. 全球教育向终身 学习迈进的新里程—— “教育 2030 行动框架” 目标译解 $[\mathrm{J}]$. 开 放教育研究, 2015, (06) : 16-25.

[5] Gong Shizu. Disscussion on University Talent Training Model [M] Nanjing: Jiangsu Education Publishing House, 1999: 16. 龚世祖. 论 大学人才培养模式 [M]. 南京: 江苏教育出版社, 1999: 16.

[6] Tao Delin. Understanding of Two Issues in the Study of Marxism in China [J]. Social Science in China Press, 2009, (01): 4-16+204. 陶德 
麟. 对马克思主义中国化研究中两个问题的理解 [J]. 中国社会科 学, 2009, (01): 4-16+204.

[7] Wang Wencheng, An Lina. Disscussion on Optimization Allocation of Physical Education Curriculum Resources in Colleges and Universities [J]. Sports Culture Guide, 2009, (08): 106-107. 王文成, 安丽娜. 论高校体育课程资源优化配置 [J]. 体育文化导 刊, 2009, (08): 106-107.

[8] Song Xiaomeng. Gu Mingyuan, President of China Education Association: Regional Education Planning Should Reflect the Characteristics of Modern Education [N]. Guangming Daily, 201001-22(003). 宋晓梦. 中国教育学会会长顾明远: 区域教育规划要 体现现代教育的特征 [N]. 光明日报, 2010-01-22 (003).

[9] Han Yun. Value Orientation of Contemporary College Students and Reconstruction of Their Values [J]. Social Sciences Journal of Universities in Shanxi, 2009, (09): 84-88. 韩芸. 当代大学生价值取 向及其价值观念重构 $[\mathrm{J}]$. 山西高等学校社会科学学 报, 2009, (09): 84-88.

[10] Berry,B.the Teacher Solutions 2030 Team(2011b).The Teachers of 2030: Creating a Student-centered Profession for the $21^{\text {st }}$ Century [R]. Center for Teaching Quality:11.

[11] Berry ,B.Moore,R. (2011). Teaching for the Future: Creating the Teaching Profession that 21st-Century Students Deserve [ EB/OL ] .http://www. Advanced. org/source/teaching-futurecreating-teaching-profession-21st-century-students-deserve-0.

[12] Li Hongsheng, Chen Gui. Thinking on the Formulation Process of Application-oriented Undergraduate Talent Training Program[J]. China Modern Education Equipment, 2011,(21):108-110. 李宏胜, 陈 桂. 应用型本科人才培养方案制定过程的思考 $[\mathrm{J}]$. 中国现代教育 装备, 2011, (21): 108-110.

[13] Chen Lei, Xiao Jing. Rational Thinking and Pluralism Construction of Higher Education Quality View [J]. China Higher Education Research, 2005, (03): 36-38. 陈否, 肖静. 高等教育质量观的理性思 考与多元化构建 $[\mathrm{J}]$. 中国高教研究, 2005, (03):36-38.

[14] Chester,E. \& Finn,Jr. (2010). American Education in 2030 [R] .2010 Board of Trustees of the Leland Stanford Junior University:4.

[15] Zhou Dejian. University Culture and the Characteristics and Thinking of University Culture Construction in Local Colleges and Universities [J]. Higher Education Forum, 2009, (05): 4-7+17. 周德俭. 大学文化 及其地方高校的大学文化建设特点与思考 $[\mathrm{J}]$. 高教论 坛, 2009, (05) : 4-7+17.

[16] Jackson,C. K. \& Bruegmann,E.( 2009 ).Teaching Students and Teaching Each Other: The Importance of Peer Learning for Teachers [J]. Washington, DC: National Bureau of Economic Research. 